
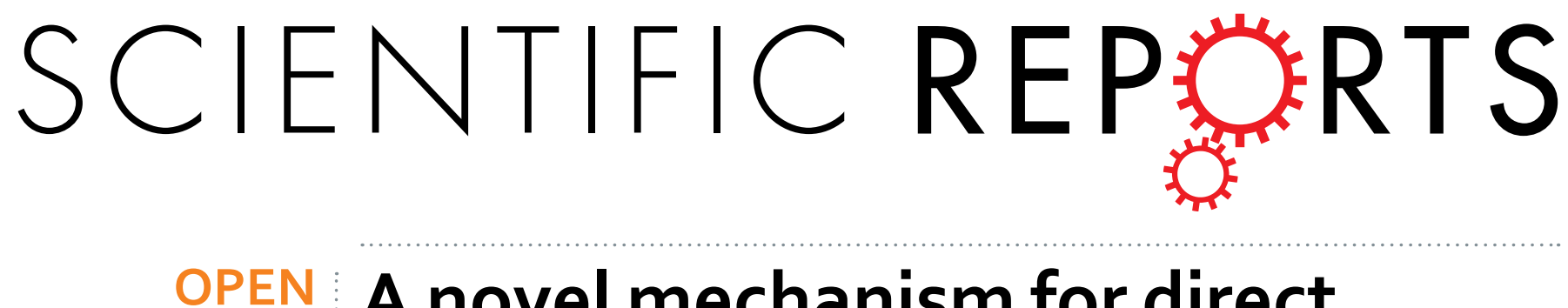

\title{
A novel mechanism for direct real-time polymerase chain reaction that does not require DNA isolation from prokaryotic cells
}

Received: 07 May 2015

Accepted: 27 May 2016

Published: 23 June 2016
Takashi Soejima ${ }^{1}$, Jin-zhong Xiao ${ }^{2} \&$ Fumiaki Abe $^{1}$

Typically, polymerase chain reaction (PCR) is performed after DNA isolation. Real-time PCR (qPCR), also known as direct qPCR in mammalian cells with weak membranes, is a common technique using crude samples subjected to preliminary boiling to elute DNA. However, applying this methodology to prokaryotic cells, which have solid cell walls, in contrast to mammalian cells which immediately burst in water, can result in poor detection. We successfully achieved PCR elongation with the addition of $1.3 \mathrm{cfu}$ of Cronobacter muytjensii to a newly developed direct qPCR master mix without performing any crude DNA extraction (detection limit of $1.6 \times 10^{\circ} \mathrm{cfu} / \mathrm{ml}$ for the test sample compared with a detection limit of $1.6 \times 10^{3} \mathrm{cfu} / \mathrm{ml}$ primarily for crude (boiling) or classical DNA isolation). We revealed that the chromosomal DNA retained in prokaryotic cells can function as a PCR template, similarly to the mechanism in in situ PCR. Elucidating this reaction mechanism may contribute to the development of an innovative master mix for direct qPCR to detect genes in a single bacterium with solid cell walls and might lead to numerous novel findings in prokaryotic genomics research.

Polymerase chain reaction (PCR) is a useful tool for the rapid detection and analysis of targeted microorganisms (particularly those that take a long time to grow or are difficult to grow artificially) in not only biochemical research samples but also food, environmental, or clinical samples ${ }^{1-7}$. Typical PCR requires time- or money-intensive DNA isolation to remove numerous PCR inhibitors ${ }^{8}$, although the DNA isolation may be partially conducted in an automated machine ${ }^{9}$.

Mammalian cells have weak cell membranes but do not have cell walls, whereas bacteria possess both ${ }^{10}$; thus, the chromosomal DNA of mammalian cells can easily be eluted from cells ${ }^{11}$. To remove the time- and money-intensive DNA isolation step, real-time PCR with crude DNA extraction (intermediate direct qPCR) through boiling has been performed with clinical samples, including hair roots. Concretely, intermediate direct qPCR has been performed by using commercially available kits, such as MightyAmp ${ }^{\circledR}$ DNA Polymerase Ver.2, to suppress the function of PCR inhibitors in experimental samples (Takara-Bio, Ohtsu, Japan) ${ }^{11}$. The goal of this experiment was to conduct simple and rapid genomic research and routine food/environmental/clinical testing to detect DNA from nearly a single prokaryotic cell with solid cell walls. Direct qPCR with crude DNA extraction (intermediate direct qPCR) for mammalian cells is commonly applied for the detection of prokaryotic cells without any modification. This method may prevent the identification of new information regarding prokaryotic cells, as a consequence of the poor detection limit, which is at best $10^{2} \mathrm{cfu} / \mathrm{ml}$, with average values of $10^{3}-10^{4} \mathrm{cfu} / \mathrm{ml}$ or g. In detail, various pathogenic bacteria and fungi have been detected in faecal samples and nasopharyngeal aspirates through intermediate direct qPCR using crude DNA extraction through boiling, although the associated microorganisms in these samples, unlike mammalian cells, have solid cell walls ${ }^{12-14}$. When considering both the recovery rate of DNA extraction from cells and the contamination with PCR inhibitors originating from the tested sample matrices, crude DNA extraction methods, such as boiling, are not recommended to obtain the lower detection limit for a microorganism ${ }^{15}$.

${ }^{1}$ Functional Food Ingredients, Food Ingredients \& Technology Institute, Morinaga Milk Industry Co., Ltd. 5-1-83, Higashihara, Zama, Kanagawa, 252-8583, Japan. ${ }^{2}$ Next Generation Science Institute, Morinaga Milk Industry Co., Ltd. 5-1-83, Higashihara, Zama, Kanagawa, 252-8583, Japan. Correspondence and requests for materials should be addressed to T.S. (email: t_soezim@morinagamilk.co.jp) 


\begin{tabular}{|c|c|c|c|}
\hline & & Washing step & $(\mathrm{Ct})^{*}$ \\
\hline \multirow{4}{*}{$\begin{array}{l}\text { C. muytjensii in saline } \\
\left(10^{8} \mathrm{cfu} / \mathrm{ml}\right)\end{array}$} & \multirow{2}{*}{ No heat } & Pellet (suspension) & $16.4 \pm 0.42^{\dagger}$ \\
\hline & & Supernatant & $21.5 \pm 0.00^{\ddagger}$ \\
\hline & \multirow{2}{*}{$\begin{array}{l}\text { Heat following } \\
\text { PCR thermal cycle }\end{array}$} & Pellet (suspension) & $14.0 \pm 0.49$ \\
\hline & & Supernatant & $15.2 \pm 0.21$ \\
\hline \multirow{4}{*}{$\begin{array}{l}\text { C. muytjensii in direct qPCR } \\
\text { components }\left(10^{8} \mathrm{cfu} / \mathrm{ml}\right)\end{array}$} & \multirow{2}{*}{ No heat } & Pellet (suspension) & $15.8 \pm 1.48$ \\
\hline & & Supernatant & $24.1 \pm 1.84$ \\
\hline & \multirow{2}{*}{$\begin{array}{l}\text { Heat following } \\
\text { PCR thermal cycle }\end{array}$} & Pellet (suspension) & $22.5 \pm 0.49$ \\
\hline & & Supernatant & $30.7 \pm 0.35$ \\
\hline
\end{tabular}

Table 1. Direct qPCR elongation products from pellets or supernatants obtained from the centrifugation of $C$. muytjensii suspensions with or without PCR thermal cycling. *Direct qPCR measurements were performed in duplicate. The Ct values are presented as the means $\pm \mathrm{SD}(\mathrm{n}=2)$. ${ }^{\dagger}$ The live cell count of $C$. muytjensii in the Pellet was $7.6 \pm 0.19 \log _{10} \mathrm{cfu} / \mathrm{ml}$ on SPC agar. ${ }^{\ddagger}$ The live cell count of C. muytjensii in the Supernatant was $5.7 \pm 0.20 \log _{10} \mathrm{cfu} / \mathrm{ml}$ on SPC agar.

Therefore, we have previously developed a series of simple and rapid real-time PCR (qPCR) techniques (direct qPCR) that do not require any DNA extraction, such as boiling, and we have applied the techniques to milk, infant formula, and blood samples ${ }^{16-21}$. The direct qPCR master mix includes a typical, real-time PCR master mix and other components, such as bovine serum albumin (BSA; Sigma, St. Louis, MO, USA), to adsorb PCR inhibitors from the test samples, a non-ionic detergent to modify the structures and dissolve the proteins of bacterial cell walls, and a calcium chelating agent ${ }^{18-21}$.

We had initially determined that this direct qPCR master mix (including the intermediate direct qPCR master mix) is more specialized than normal PCR master mix in adsorbing many of the PCR inhibitors present in samples $^{20,22}$. However, the recovery rate of chromosomal DNA eluted from bacterial cells with this direct qPCR master mix remains unknown ${ }^{18-21}$. The soft membranes of mammalian cells easily burst under hyperosmolarity or hypoosmolarity, thus allowing intermediate direct qPCR elongation through the additional boiling of crude DNA extractions ${ }^{23,24}$. However, unlike mammalian cells, prokaryotic cells have solid cell walls ${ }^{10,25}$. Nonetheless, the mechanism of amplification when prokaryotic cells (and fungi) are directly added into a commercial direct qPCR master mix has not been elucidated ${ }^{12-14,18-21}$.

Indeed, there is a demand for new and precise methodologies for direct qPCR to obtain much lower detection limits for prokaryotic cells, including a more suitable direct qPCR master mix for prokaryotic cells ${ }^{12-14}$. Thus, in the present study, we present a viable method for in situ PCR that facilitates the physical elongation of DNA in prokaryotic cells concerning our direct qPCR. Herein, we succeeded in effectively elongating a target gene in nearly one prokaryotic cell of Cronobacter without performing any DNA extraction such as boiling. Because a low detection limit has never been obtained for prokaryotic cells through intermediate direct qPCR using crude (boiling) or classical approaches involving preventive DNA isolation ${ }^{12-14}$, here we report the detailed outcomes of the present study.

\section{Results}

PCR measurements to evaluate the disruption rate of $C$. muytjensii cell through PCR thermal

cycling. To evaluate the disruption rate of $C$. muytjensii cells during PCR thermal cycling, PCR elongation was performed using a direct qPCR master mix for the pellet and supernatant obtained from C. muytjensii previously subjected to 50 rounds of PCR thermal cycling in physiological saline or direct qPCR components (see the Methods section) (Table 1). The direct qPCR master mix comprised of the direct qPCR components, in which the volume of sterile water (SW) was reduced to $2.7 \mu \mathrm{l}$, and the typical PCR master mix including Taq, specific (ompA) primers for C. muytjensii, and SYBR Green I.

The effects of matrices with direct qPCR components before and after PCR thermal cycling on PCR elongation were evaluated, to accurately evaluate Table 1 (Table 2). With respect to the samples amplified without thermal cycling (hereafter termed non-heated), we used C. muytjensii in physiological saline. A comparison of the Ct values for the suspension (corresponding to Pellet in Table 1) and Supernatant (Table 1) obtained through centrifugation revealed that the $\mathrm{Ct}$ values for the Pellet group were approximately $5 \mathrm{Ct}$ units lower than those of the Supernatant group. In contrast, given the experimentally determined PCR efficiency (average of 2.1 nearing theoretical value of 2.0) calculated in the range of $2.5 \times 10^{3}$ to $2.5 \times 10^{6} \mathrm{cfu} / \mathrm{PCR}$ for C. muytjensii in saline (Table 2), the number of PCR amplicons increased approximately $10^{1}$-fold $\left(2.1^{3.2}\right.$-fold $)$ after 3.2 cycles of PCR, and the Pellet group was approximately $5 \mathrm{Ct}$ units lower than the Supernatant group, thus suggesting that the DNA amount in the Pellet group was $2.1^{5}$-fold $\left(1.6 \log _{10}\right.$-fold) higher than that in the Supernatant group ${ }^{26}$. In relation to the $C$. muytjensii suspension with direct qPCR components, the Ct values for the Pellet group were 8.2 to $8.3 \mathrm{Ct}$ units lower than those of the Supernatant group, regardless of PCR thermal cycling parameters (Table 1). Concerning the inhibitory effect of direct qPCR components compared with saline, no significant differences were observed before or after PCR thermal cycling between the Pellet and Supernatant groups (Table 2). The PCR efficiencies were calculated in a range from $2.5 \times 10^{3}$ to $2.5 \times 10^{6} \mathrm{cfu} / \mathrm{PCR}$ for $C$. muytjensii in the Pellet and Supernatant groups with and without PCR thermal cycling, and the efficiency values were 2.2 (Pellet with non-heated direct qPCR components), 2.1 (Supernatant with non-heated components), 2.1 (Pellet with heated components), and 2.1 (Supernatant with heated components). These calculations suggest that the DNA amounts in the Pellet groups 


\begin{tabular}{|c|c|c|c|c|c|}
\hline \multirow{3}{*}{$\begin{array}{l}\text { C. muytjensii } \\
\text { live cells/PCR } \\
\text { (cfu/PCR tube) }\end{array}$} & \multirow{3}{*}{$\begin{array}{l}\text { Physiological } \\
\text { saline (Ct) }\end{array}$} & \multicolumn{4}{|c|}{ Direct qPCR components } \\
\hline & & \multicolumn{2}{|c|}{ No heat $(\mathrm{Ct})$} & \multicolumn{2}{|c|}{$\begin{array}{l}\text { Heat following PCR therma } \\
\text { cycling }(\mathrm{Ct})\end{array}$} \\
\hline & & Pellet $^{\dagger}$ & Supernatant $^{*}$ & Pellet $^{\dagger}$ & Supernatant ${ }^{\ddagger}$ \\
\hline $2.5 \times 10^{6}$ & $14.5 \pm 0.49^{*}$ & $15.0 \pm 0.65$ & $14.9 \pm 0.58$ & $14.7 \pm 0.64$ & $14.6 \pm 0.66$ \\
\hline $2.5 \times 10^{5}$ & $17.3 \pm 0.71$ & $16.3 \pm 0.41$ & $16.4 \pm 0.43$ & $16.8 \pm 0.63$ & $16.7 \pm 0.58$ \\
\hline $2.5 \times 10^{4}$ & $20.9 \pm 0.31$ & $20.6 \pm 0.47$ & $20.5 \pm 0.42$ & $20.5 \pm 0.58$ & $20.3 \pm 0.51$ \\
\hline $2.5 \times 10^{3}$ & $23.8 \pm 1.13$ & $24.0 \pm 0.72$ & $24.2 \pm 0.71$ & $24.2 \pm 0.75$ & $24.0 \pm 0.63$ \\
\hline
\end{tabular}

Table 2. Effects of sample matrices on direct qPCR. *Direct qPCR measurements were performed in duplicate. The $\mathrm{Ct}$ values are presented as the means $\pm \mathrm{SD}(\mathrm{n}=2)$. ${ }^{\dagger}$ The pellet was obtained through the centrifugation of the direct qPCR master mix with or without PCR thermal cycling. The freshly prepared direct qPCR master mix was added to the pellet to generate the matrices of labelled Pellet. These matrices were used to suspend C. muytjensii. ${ }^{\ddagger}$ The supernatant was obtained through the centrifugation of direct qPCR master mix with or without PCR thermal cycling. These supernatants were used as the matrices labelled Supernatant to suspend C. muytjensii.

could be $2.1^{8.2}-2.2^{8.3}$-fold $\left(2.6-2.8 \log _{10}\right.$-fold $)$ higher than those in the Supernatant groups, regardless of PCR thermal cycling (Table 2).

In addition, the Ct values of the Pellet and Supernatant groups for C. muytjensii suspended in the direct qPCR components after PCR thermal cycling were by 6.6 to 6.7 higher than those of the Pellet and Supernatant groups, prior to PCR thermal cycling (rows 5 and 6, and rows 7 and 8 in Table 1). These significantly higher Ct values did not result from the inhibitory effects of the sample matrices of the direct qPCR components after PCR thermal cycling, because there were no significant differences in the PCR elongation between saline and direct qPCR components before and after PCR thermal cycling (Table 2). However, the originally transparent direct qPCR components became cloudy after 50 cycles of PCR thermal cycling (see cloudy particles of the second half and right-side image in Fig. 1). When C. muytjensi was suspended in the cloudy direct qPCR components, and this was followed by PCR in newly prepared direct qPCR master mix, no inhibitory effects were observed (Table 2). This result suggests that $C$. muytjensii exposed to gradually producing clouded compartments of the direct qPCR components could not immediately function as a PCR template in successive direct qPCR, reflecting adsorption and/or folding of the cloudy components.

To estimate the number of non-heated C. muytjensii cells suspended in saline that were recovered in the Supernatant through centrifugation, live bacterial counts were obtained after growth on standard plate count agar medium (SPC agar: Eiken, Tokyo, Japan) for the Supernatant and Pellet groups (Table 1). The live C. muytjensii cell counts for the Pellet and Supernatant groups were $7.6 \pm 0.19$ and $5.7 \pm 0.20 \log _{10} \mathrm{cfu} / \mathrm{ml}$, respectively. This result shows that the live count for the Pellet group was approximately $1.9 \log _{10} \mathrm{cfu} / \mathrm{ml}$ unit higher (by $1 \ll 2 \log _{10}$ $\mathrm{cfu} / \mathrm{ml}$ unit order for raw counting data) than that of the Supernatant group. Regarding the non-heated C. muytjensii suspension in physiological saline, the PCR data were highly consistent with that of the SPC counts.

Morphological analysis of $C$. muytjensii cells in physiological saline or direct qPCR components after PCR thermal cycling. Fluorescence microscopy and flow cytometry (FCM) measurements using SYTO9 nucleic acid staining (Molecular Probes, Inc., Eugene, OR, USA), which penetrates into both intact and compromised cell walls/inner membranes of C. muytjensii, were performed to determine whether C. muytjensii retained their morphology after PCR thermal cycling (Figs 1-3).

As observed in the green fluorescent bacteria (Fig. 1), significant differences between the suspended pellets (corresponding to Pellet in Table 1) and supernatant (corresponding to Supernatant in Table 1) occurred with and without PCR thermal cycling, regardless of the different suspension matrices (saline and the direct qPCR components). In both matrices, after PCR thermal cycling, the green fluorescent bacteria retained the morphology of bacterial cells with chromosomal DNA, and the numbers were at the same level as that before PCR cycling for the suspended pellets (Fig. 1).

The FCM assays for C. muytjensii suspended in saline before and after PCR thermal cycling are shown in Fig. 2. Similarly, the FCM assays for C. muytjensii suspended in the direct qPCR components before and after thermal cycling are presented in Fig. 3. The plot number in the SYTO9 quadrant (+)/FL3-H(-) for the C. muytjensii suspension in saline after PCR thermal cycling was approximately $80 \%$ of that before thermal cycling (Fig. 2). In contrast, relative to the comparison between C. muytjensii suspended in the direct qPCR components before and after PCR thermal cycling, the plot number of SYTO9 (+)/FL3-H (-) for the C. muytjensii after PCR thermal cycling was the same as that of the associated cell suspension before PCR cycling (Fig. 3), suggesting that the C. muytjensii in the direct qPCR components was not degraded through PCR thermal cycling.

The degree of PCR elongation and the FCM assay for C. muytjensii subjected to fixation before, during, and after direct qPCR measurements. To determine whether PCR elongation through direct qPCR is similar to that in in situ PCR, we performed direct qPCR elongation ( 0,15 , or 30 cycles) on C. muytjensii with preliminary fixation A ( $4 \%$ paraformaldehyde, PFA) or B (methanol/acetic acid =3/1) (Fig. 4) and also performed FCM assays (SYTO9 staining) for the direct qPCR products at 0,15 , or 30 cycles on fixed cells (Tables 3 and 4). Although the chromosomal DNA was retained in C. muytjensii cells after fixation, the gel-electrophoresed bands for both supernatants obtained through centrifugation after direct qPCR with 30 cycles were positive 


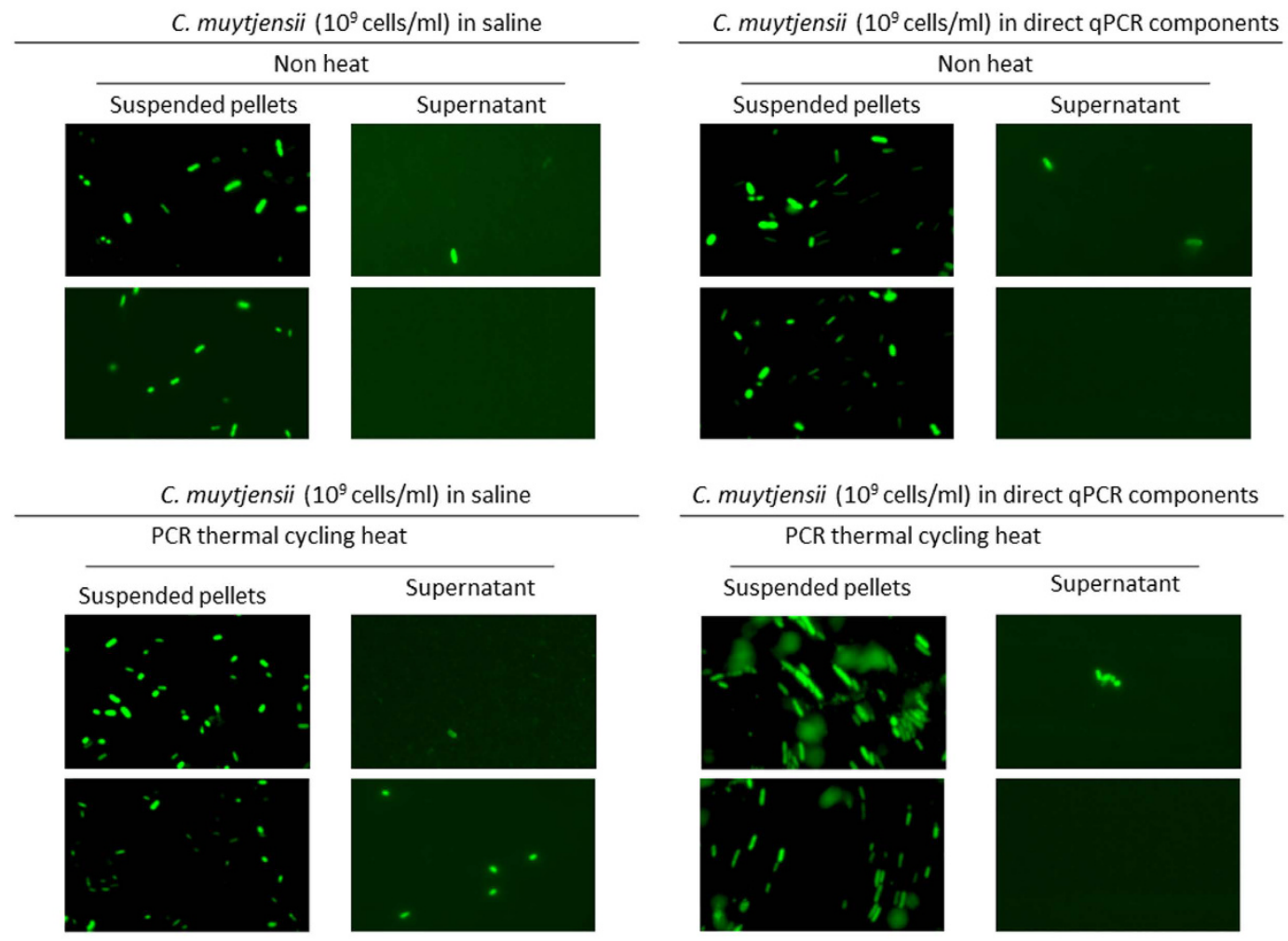

Figure 1. Fluorescence microscopy images (SYTO9) of $C$. muytjensii in physiological saline or the direct qPCR components before or after PCR thermal cycling.

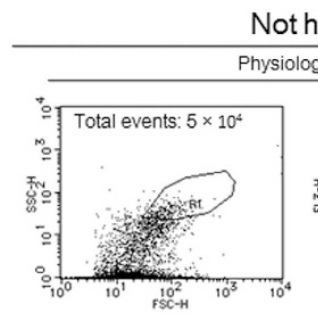

Not heated iological saline
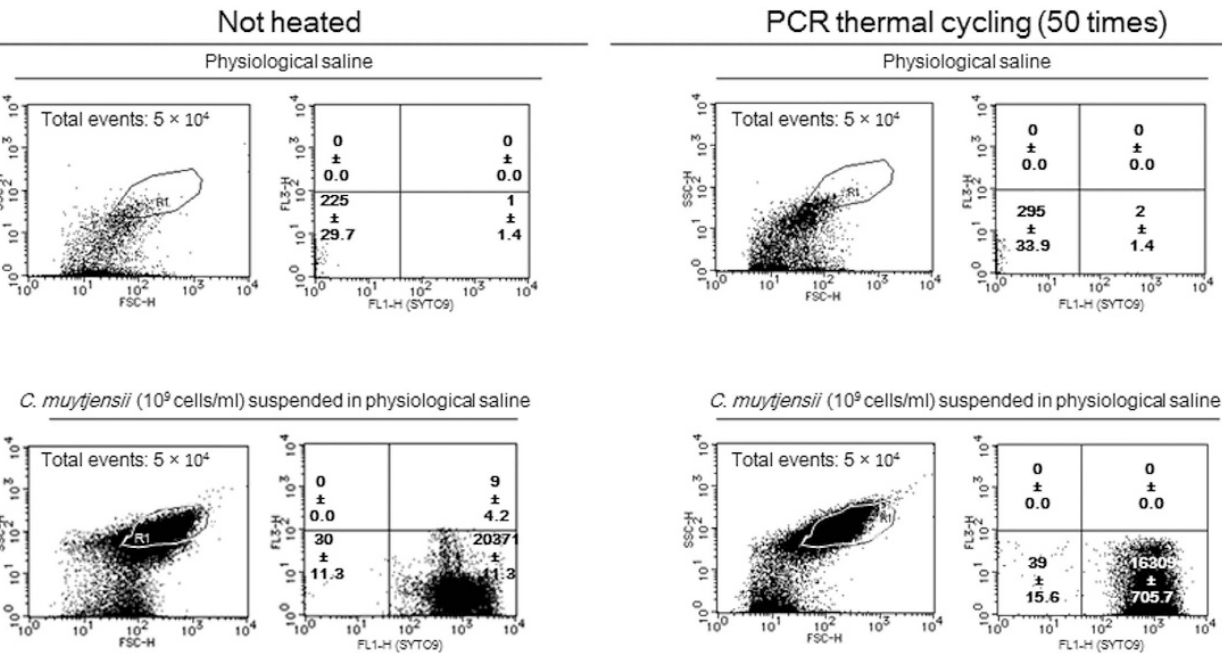

Figure 2. FCM assay with SYTO9 of C. muytjensii in physiological saline before or after PCR thermal cycling. The particles in the gate R1 in an FSC-H-SSC-H plot, were plotted on quadrants in the SYTO9-FL3-H graph. The FCM measurements were completed in duplicate, and the particle numbers of quadrants are presented as the means $\pm S D(n=2)$.

(Fig. 4). In contrast, compared with the quadrant numbers of the SYTO9 (+)/FL3-H (-) in the FCM plots for the pellets obtained through centrifugation of the direct QPCR products at 0,15 , or 30 cycles, there were few significant differences between either fixation method (Fig. 4). These results suggest that a large part of the chromosomal DNA from the fixed cells was retained in the cells, but that PCR elongations took place; as a consequence, the elongated amplicons (ompA of $469 \mathrm{bp}$ ) were released from the bacterial cells into the external direct qPCR master mix. 

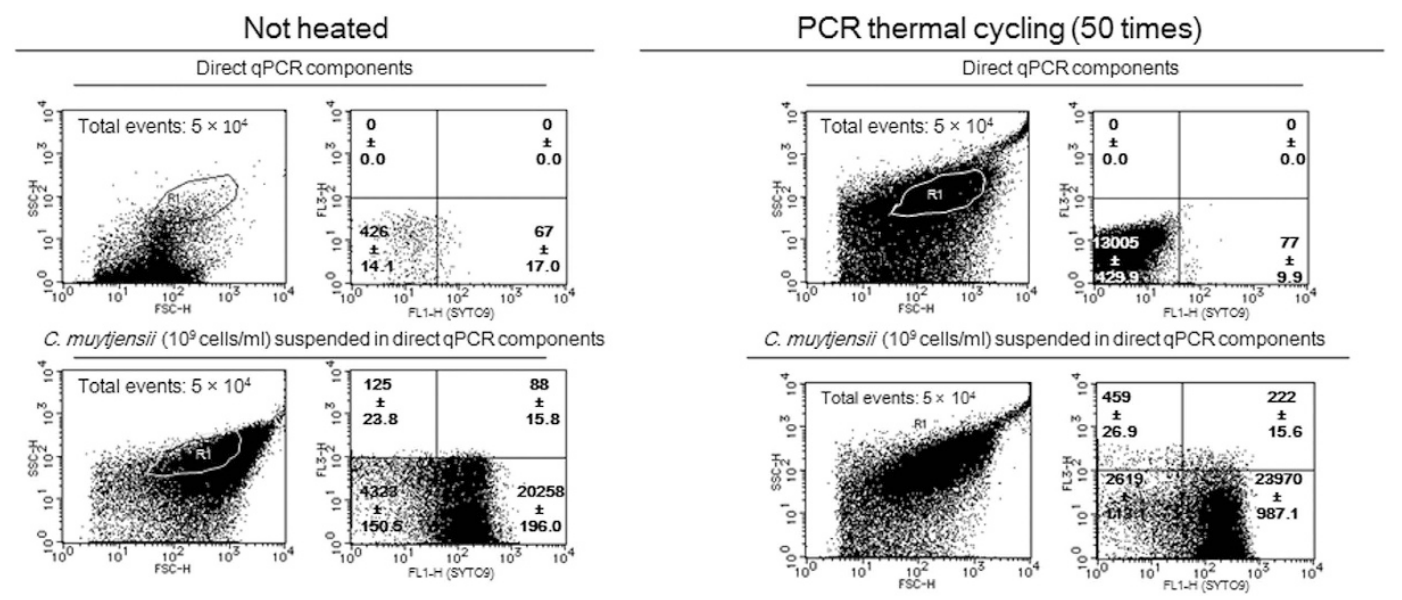

Figure 3. FCM assay with SYTO9 for C. muytjensii in the direct QPCR components before or after PCR thermal cycling. The particles in the gate R1 in an FSC-H-SSC-H plot were plotted on quadrants in the SYTO9FL3-H graph. The FCM measurements were completed in duplicate, and the particle numbers of the quadrants are presented as the means $\pm S D(n=2)$.

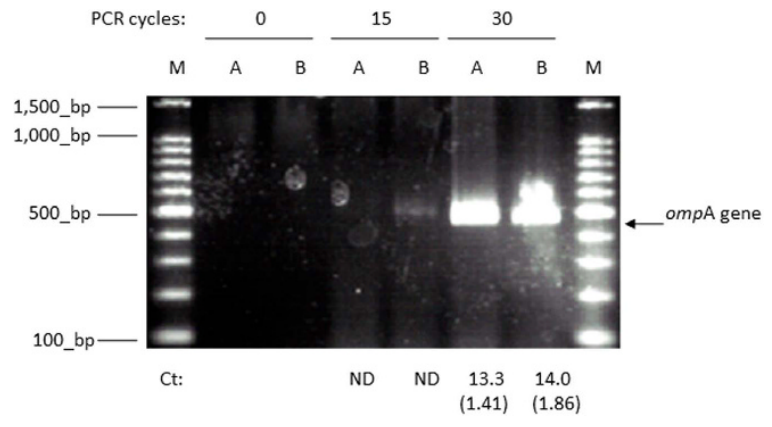

Figure 4. Gel-electrophoresis of the supernatant resulting from the direct qPCR master mix containing the fixed C. muytjensii cells before, during, or after direct qPCR. A 2.0\% agarose gel was used. M: 100 bp DNA ladder; A: fixation with $4 \%$ paraformaldehyde (4\% PFA); B: fixation with methanol/acetic acid (3/1). Under the gel image, the Ct values of the associated direct qPCR are presented as the means \pm SD in parenthesis $(n=2)$; ND: no elongation.

Direct qPCR is similar to in situ PCR. When PCR elongation and in situ PCR were conducted in the $C$. muytjensii cells, the typically short DNA amplicons (i.e., ompA of $469 \mathrm{bp}$ ) were eluted from the bacterial cells (Fig. 4); thus, to ascertain that the PCR amplicons resulted from in situ PCR in bacterial cells, long DNA amplifications for C. muytjensii with no fixation (labelled as S in Fig. 5) or fixation B (methanol/acetic acid $=3 / 1$ labelled as B in Fig. 5) were performed. Figure 5 indicates that long DNA amplicons (16S-23S rRNA gene; approximately $2,450 \mathrm{bp}$ ) were retained in bacterial cells. Next, DNA extraction was performed using the pellets obtained through centrifugation of the PCR products (followed by combining 20 PCR tubes) after direct qPCR. As presented in lanes 4 and 5 of Fig. 5, the presence of long DNA PCR amplicons $(2,450 \mathrm{bp})$ was confirmed. As a control, DNA extractions were performed on the pellets obtained through centrifugation of the PCR reaction mixture (combining 20 PCR tubes) prior to direct qPCR, and no bands were detected (lanes 2 and 3 in Fig. 5). These results suggest that the long DNA amplicons, at least in part, were retained in C. muytjensii cells.

Comparison of the detection limits for Cronobacter cells after direct qPCR or qPCR following crude DNA extraction or DNA purification. We obtained $1 \mathrm{ml}$ of $1.6 \times 10^{0}-1.6 \times 10^{5} \mathrm{cfu} / \mathrm{ml}$ of the $C$. sakazakii and C. muytjensii suspensions in SW, on which we performed direct qPCR amplification or qPCR elongation after crude DNA extraction (boil for $10 \mathrm{~min}$ ) or DNA purification using the FastPure DNA Kit (Takara Bio). The results are presented in Table 5. As a control, qPCR standards of the serially diluted purified chromosomal DNA are also shown in Table 5. The Ct values for the DNA (qPCR standards) and Cell (direct qPCR using Cronobacter cells) groups in Table 5 were approximately the same between the relevant cell numbers of $C$. sakazakii or C. muytjensii, suggesting that nearly $100 \%$ of the chromosomal DNA retained in the cells was available for direct qPCR elongation. The following detection limis for each method (Table 5) were observed: $1.6 \times 10^{0} \mathrm{cfu} / \mathrm{ml}$ (corresponding to $1.3 \times 10^{\circ} \mathrm{cfu} / \mathrm{PCR}$ ) for DNA (qPCR standards) and Cell (direct qPCR), $1.6 \times 10^{2}$ (C. sakazakii) or $1.6 \times 10^{3} \mathrm{cfu} / \mathrm{ml}$ (C. muytjensii) for the Clean-up methods, and $1.6 \times 10^{3} \mathrm{cfu} / \mathrm{ml}$ (both Cronobacter species) for the Boil methods. Comparison of the detection limits for Cronobacter revealed that the direct qPCR system 


\begin{tabular}{|c|c|c|c|}
\hline Fix: 0 cycle & Quadrant & Events & $\begin{array}{l}\text { Quadrant rate in } \\
\text { gated events (\%) }\end{array}$ \\
\hline & UL* & $0 \pm 0.0$ & $0.00 \pm 0.00$ \\
\hline Total events: $5 \times 10^{4}$ & $\mathrm{UR}^{\dagger}$ & $2 \pm 0.7$ & $0.01 \pm 0.00$ \\
\hline \multirow[t]{2}{*}{ Gated events: $18994 \pm 785.6$} & $\mathrm{LL}^{\ddagger}$ & $539 \pm 38.2$ & $2.84 \pm 0.20$ \\
\hline & $\mathrm{LR}^{\S}$ & $18453 \pm 748.1$ & $97.16 \pm 3.94$ \\
\hline \multicolumn{4}{|l|}{ Fix: 15 cycles } \\
\hline & UL & $0 \pm 0.0$ & $0.00 \pm 0.00$ \\
\hline Total events: $5 \times 10^{4}$ & UR & $3 \pm 2.1$ & $0.02 \pm 0.01$ \\
\hline \multirow[t]{2}{*}{ Gated events: $16648 \pm 1030.3$} & LL & $69 \pm 13.4$ & $0.41 \pm 0.08$ \\
\hline & LR & $16577 \pm 1014.7$ & $99.58 \pm 6.10$ \\
\hline \multicolumn{4}{|l|}{ Fix: 30 cycles } \\
\hline & UL & $0 \pm 0.0$ & $0.00 \pm 0.00$ \\
\hline Total events: $5 \times 10^{4}$ & UR & $7 \pm 2.1$ & $0.04 \pm 0.01$ \\
\hline \multirow[t]{2}{*}{ Gated events: $16394 \pm 971.6$} & LL & $1602 \pm 54.4$ & $9.78 \pm 0.33$ \\
\hline & LR & $14786 \pm 915.0$ & $90.19 \pm 5.58$ \\
\hline
\end{tabular}

Table 3. FCM assay (SYTO9) for C. muytjensii with preliminary fixation of $4 \%$ paraformaldehyde before, during, or after the direct qPCR. *UL presents Upper Left FCM quadrants, that is SYTO9 (-)/FL3-H (+). ${ }^{\dagger} \mathrm{UR}$ presents Upper Right FCM quadrants, that is SYTO9 $(+) / \mathrm{FL} 3-\mathrm{H}(+) .{ }^{\ddagger} \mathrm{LL}$ indicates Lower Left FCM quadrants, that is SYTO9 (-)/FL3-H (-). ${ }^{\varsigma}$ LR indicates Lower Right FCM quadrants, that is SYTO9 (+)/FL3-H (-).

\begin{tabular}{|c|c|c|c|}
\hline Fix: 0 cycle & Quadrant & Events & $\begin{array}{l}\text { Quadrant rate in } \\
\text { gated events (\%) }\end{array}$ \\
\hline & $\mathrm{UL}^{*}$ & $0 \pm 0.0$ & $0.00 \pm 0.00$ \\
\hline Total events: $5 \times 10^{4}$ & $\mathrm{UR}^{\dagger}$ & $3 \pm 1.4$ & $0.02 \pm 0.01$ \\
\hline \multirow[t]{2}{*}{$\begin{array}{l}\text { Gated events: } \\
16959 \pm 1149.8 \\
\end{array}$} & $\mathrm{LL}^{*}$ & $5266 \pm 174.7$ & $31.09 \pm 1.03$ \\
\hline & $\mathrm{LR}^{\S}$ & $11691 \pm 973.7$ & $68.90 \pm 5.74$ \\
\hline \multicolumn{4}{|l|}{ Fix: 15 cycles } \\
\hline & UL & $0 \pm 0.0$ & $0.00 \pm 0.00$ \\
\hline Total events: $5 \times 10^{4}$ & UR & $2 \pm 0.7$ & $0.01 \pm 0.00$ \\
\hline \multirow[t]{2}{*}{ Gated events: $16372 \pm 610.2$} & $\mathrm{LL}$ & $3671 \pm 84.1$ & $22.43 \pm 0.51$ \\
\hline & LR & $12700 \pm 525.4$ & $77.57 \pm 3.21$ \\
\hline \multicolumn{4}{|l|}{ Fix: 30 cycles } \\
\hline & UL & $0 \pm 0.0$ & $0.00 \pm 0.00$ \\
\hline Total events: $5 \times 10^{4}$ & UR & $4 \pm 1.4$ & $0.03 \pm 0.01$ \\
\hline \multirow[t]{2}{*}{ Gated events: $14142 \pm 553.7$} & LL & $1394 \pm 53.0$ & $9.86 \pm 0.37$ \\
\hline & LR & $12844 \pm 357.8$ & $90.82 \pm 2.53$ \\
\hline
\end{tabular}

Table 4. FCM assay (SYTO9) for C. muytjensii with preliminary fixation of (methanol/acetic acid = 3/1) mixture before, during, or after the direct qPCR. *UL presents Upper Left FCM quadrants, that is SYTO9 $(-) / F L 3-H(+) .{ }^{\dagger} \mathrm{UR}$ presents Upper Right FCM quadrants, that is SYTO9 $(+) / \mathrm{FL} 3-\mathrm{H}(+) .{ }^{\ddagger} \mathrm{LL}$ indicates Lower Left FCM quadrants, that is SYTO9 $(-) / \mathrm{FL} 3-\mathrm{H}(-) .{ }^{\varsigma} \mathrm{LR}$ indicates Lower Right FCM quadrants, that is SYTO9 $(+) / F L 3-H(-)$.

utilizing in situ PCR for prokaryotic cells was superior to qPCR following crude or purified DNA extraction, indicating a significant advantage in the robust detection of nearly one singular bacterial cell.

\section{Discussion}

When the DNA or RNA recovery from bacteria is nearly $100 \%$, using crude extraction techniques, such as boiling, before intermediate direct qPCR could succeed in detecting a single cell. However, as previously discussed, the detection limit for prokaryotic cells and fungi, through intermediate direct qPCR using boiling is at best $10^{2}$ $\mathrm{cfu} / \mathrm{ml}$, with an average of $10^{3}$ to $10^{4} \mathrm{cfu} / \mathrm{ml}$ or $\mathrm{g}^{12-14}$. Therefore, we used direct qPCR, which does not depend on crude DNA extractions. Initially, when C. muytjensii cells were directly added to the direct qPCR master mix (see the Methods section), we incorrectly presumed that the DNA elution from these microorganisms into the external direct qPCR master mix might be induced during PCR thermal cycling. Briefly, we thought that repeated increases in the temperature would cause physical injury to the C. muytjensii; thus, thermal cycling would correspond to the aforementioned crude DNA extraction methods. As described in the Methods section, the direct qPCR master mix used in the present study comprises a 2-fold higher concentration of DNA polymerase and an approximately 2.4-fold higher concentration of $\mathrm{Mg}^{2+}$ and primers than the commercial MightyAmp direct qPCR master mix (Takara-Bio). Furthermore, our new mix has a unique combination of the PCR additives, including 


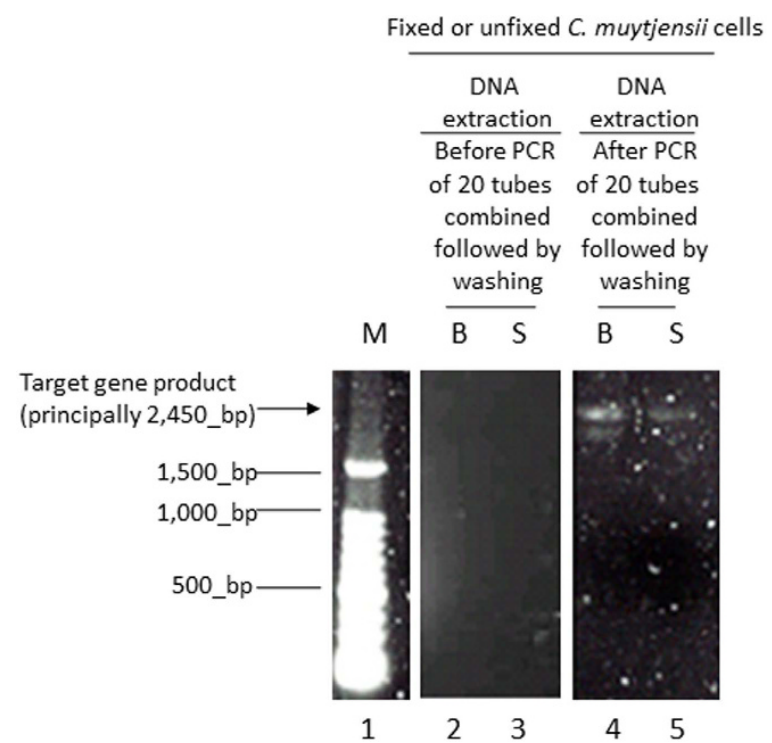

Figure 5. Electrophoresis images of DNA extracted from the $C$. muytjensii cells with or without fixation followed by direct qPCR producing long DNA amplicons. M: $100 \mathrm{bp}$ DNA ladder; B: fixation B (methanol/ acetic acid =3/1); S: no fixation (use of physiological saline); Target gene length: principally 2,451 bp of the $16 \mathrm{~S}$ to $23 \mathrm{~S}$ rRNA gene.

\begin{tabular}{|c|c|c|c|c|c|c|c|}
\hline Bacteria conc. (cfu/ml) & & $1.6 \times 10^{5}$ & $1.6 \times 10^{4}$ & $1.6 \times 10^{3}$ & $1.6 \times 10^{2}$ & $1.6 \times 10^{1}$ & $1.6 \times 10^{0}$ \\
\hline \multirow{4}{*}{ C. sakazakii ATCC29544 } & DNA* $^{*}$ & $22.1 \pm 0.78$ & $25.2 \pm 0.42$ & $28.6 \pm 0.85$ & $32.3 \pm 0.99$ & $36.1 \pm 1.13$ & $41.9 \pm 1.56$ \\
\hline & $\mathrm{Cell}^{\dagger}$ & $21.6 \pm 0.44$ & $25.0 \pm 0.26$ & $28.9 \pm 0.78$ & $32.2 \pm 0.75$ & $35.6 \pm 0.92$ & $40.6 \pm 1.27$ \\
\hline & Clean-up ${ }^{*}$ & $26.2 \pm 0.63$ & $29.5 \pm 0.55$ & $35.3 \pm 1.03$ & $\mathrm{ND} \times 2$ & $\mathrm{ND} \times 2$ & $\mathrm{ND} \times 2$ \\
\hline & Boill $^{*}$ & $28.8 \pm 0.69$ & $32.3 \pm 0.61$ & $38.2 \pm 1.14$ & $\mathrm{ND} \times 2$ & $\mathrm{ND} \times 2$ & $\mathrm{ND} \times 2$ \\
\hline \multirow{4}{*}{ C. muytjensii ATCC51329 } & DNA* $^{*}$ & $19.9 \pm 0.71^{9}$ & $23.4 \pm 0.35$ & $26.0 \pm 0.85$ & $30.7 \pm 0.85$ & $35.4 \pm 1.13$ & $40.2 \pm 1.70$ \\
\hline & $\mathrm{Cell}^{\dagger}$ & $18.3 \pm 0.52$ & $21.8 \pm 0.51$ & $24.5 \pm 0.69$ & $29.4 \pm 0.84$ & $34.8 \pm 0.86$ & $39.6 \pm 1.03$ \\
\hline & Clean-up & $23.3 \pm 0.62$ & $27.8 \pm 0.54$ & $31.6 \pm 0.77$ & $37.1 \pm 1.15$ & $\mathrm{ND} \times 2$ & $\mathrm{ND} \times 2$ \\
\hline & Boil $^{*}$ & $25.4 \pm 0.71$ & $28.9 \pm 0.73$ & $33.9 \pm 0.89$ & $\mathrm{ND} \times 2$ & $\mathrm{ND} \times 2$ & $\mathrm{ND} \times 2$ \\
\hline
\end{tabular}

Table 5. Comparison between direct qPCR without any DNA extraction and qPCR with crude or purified DNA extraction. *DNA represents qPCR using serially diluted purified chromosomal DNA. ${ }^{\dagger}$ Cell represents direct qPCR using Cronobacter cells (all of the pellet obtained through centrifugation of 1-ml suspension) without DNA extraction. Through centrifugation of $1.6 \times 10^{5} \mathrm{cfu} / \mathrm{ml}$ of bacterial suspension (1-ml), SPC counts revealed that $1.3 \times 10^{5} \mathrm{cfu}$ of Cronobacter cells was recovered in the pellet. ${ }^{\ddagger}$ Clean-up indicates DNA purification using FastPure DNA Kit (Takara Bio) for 1-ml suspension; subsequently, an aliquot of $5 \mu$ l of purified DNA solution $(200 \mu \mathrm{l})$ was used for qPCR. Boil indicates the crude extraction of boiling 1-ml suspension for $10 \mathrm{~min}$; subsequently, an aliquot of $5 \mu \mathrm{l}$ of the supernatant obtained through centrifugation of the boiled suspension (1-ml) was used for qPCR. 'The estimated chromosomal DNA amounts in $1.3 \times 10^{5} \mathrm{cfu}$ of C. sakazakii, using the equation, $1 \mathrm{cfu}=5 \mathrm{fg}$ of chromosomal DNA, were used for qPCR measurements $(\mathrm{n}=2)$, and the Ct values are presented as the means $\pm \mathrm{SD}(\mathrm{n}=2)$.

BSA, lysozyme, non-ionic detergent of polyoxyethylene (10) cetyl ether (Brij56), and trisodium citrate dehydrate (TSC) (for details, see Supplementary Table 1). However, we had initially added a higher concentration of the aforementioned components to accelerate PCR elongation at the highest possible reactivity under many the PCR inhibitors present in milk and blood samples ${ }^{15}$.

If DNA from the Cronobacter cells were indeed eluted into the external direct qPCR master mix during PCR thermal cycling, the chromosomal DNA would be mainly distributed in the supernatant but not in the bacterial pellets obtained through centrifugation after direct qPCR. However, the comparison of Ct values in rows 7 and 8 of Table 1 revealed that the Ct of the Pellet was 8.2 units lower than the Ct of the Supernatant; thus, the DNA could be distributed in the pellets at a ratio of more than 100-fold higher than that in the supernatant, considering the actual PCR efficiency experimentally obtained from Table 2 . Therefore, we discarded the previous hypothesis and proposed that direct qPCR without crude DNA extraction might use the same reaction mechanism as that of in situ $\mathrm{PCR}^{27}$ because the DNA elution from bacterial cells into the direct qPCR master mix did not occur (rows 7 and 8 in Table 1). In situ PCR is a biotechnological approach that facilitates PCR elongation in prokaryotic and eukaryotic cells. Target cells need exposure to a low dose of protease, brief heating period or electron irradiation 
because typical in situ PCR requires that the cell walls/inner membranes be compromised to allow effective penetration of all the in situ PCR master mix components, including DNA polymerase, into the targeted cells $\mathrm{s}^{27}$. Furthermore, each PCR master mix component of the in situ PCR must be significantly higher in concentration than the components in a typical PCR to facilitate the penetration of all master mix components into the cells ${ }^{27}$. Particularly, the DNA polymerase concentration for in situ PCR should ideally be 10-fold higher than that in typical PCR, and the $\mathrm{Mg}^{2+}$ concentration must be increased 2 -fold. As previously mentioned, the components in the direct qPCR master mix used in the present study meet the requirements for in situ PCR.

According to Figs 1 and 3, nearly 100\% of C. muytjensii cells suspended in the direct qPCR components maintained normal morphology and retained chromosomal DNA after PCR thermal cycling. As previously estimated, direct qPCR utilized the chromosomal DNA retained in C. muytjensii cells as a PCR template. Therefore, to ascertain that the mechanism of direct qPCR is similar to that of in situ PCR, we determined that the PCR elongation proceeded in fixed C. muytjensii cells whose chromosomal DNA was bound to membrane proteins originating from the bacterial cells; and then, its genome DNA was retained in the cells in the direct qPCR system (Fig. 4). Furthermore, according to the FCM assay and fluorescence microscopy analysis, increased thermal cycling did not accelerate the disruption of C. muytjensii cells in direct qPCR (Tables 3 and 4, Figs 1 and 3 ). Thus, the chromosomal DNA inside C. muytjensii cells emitted green fluorescence derived from SYTO9, which intercalated with the double-stranded chromosomal DNA (Tables 3 and 4, Figs 1 and 3).

Additionally, the confirmation of green fluorescent bacteria in the supernatant under the four different conditions revealed the presence of $C$. muytjensii having chromosomal DNA in the supernatant obtained through centrifugation (Fig. 1), at a level less than $10 \%$ of that in the relevant suspended pellets (Fig. 1), suggesting that the DNA elongation of Supernatant samples shown in Table 1 could result from the aforementioned retained C. muytjensii cells but not the chromosomal DNA eluted into the Supernatant.

Therefore, we demonstrated at an initial stage of the direct qPCR that the chromosomal DNA retained in microorganisms could function as a PCR template comparable to that used in in situ PCR.

As another approach to indicate that the direct qPCR for prokaryotic cells was comparable to in situ PCR, we revealed the presence of long amplicons (primarily $2,450 \mathrm{bp}$ of the $16 \mathrm{~S}$ to $23 \mathrm{~S}$ rRNA gene) in C. muytjensii cells (lanes 4 and 5 in Fig. 5). This result confirmed that the PCR elongation was comparable to that of in situ PCR.

Next, a comparison of the Ct values of the DNA (qPCR standards) and Cell (direct qPCR) samples shown in Table 5 revealed that the chromosomal DNA of nearly $100 \%$ of the Cronobacter cells could be utilized as the PCR template in direct qPCR. The direct qPCR master mix used in the present study, which was designed for in situ PCR for prokaryotic cells, is responsible for the low detection limit of $1.6 \times 10^{0} \mathrm{cfu} / \mathrm{ml}\left(1.3 \times 10^{0} \mathrm{cfu} / \mathrm{PCR}\right)$ for direct qPCR (Cell in Table 5). Furthermore, a low detection limit for Cronobacter cells with direct qPCR are never obtained through qPCR using purified or crudely extracted DNA (Clean-up or Boil in Table 5). Therefore, the direct qPCR master mix developed in the present study facilitated the detection of bacterial cells of interest in typical research samples in which the levels of these cells was below the detection limit of typical PCR using various DNA purification methods or crude extraction.

Moreover, concerning the discrimination of live from dead microorganisms of interest, the potential use of ethidium monoazide (EMA) or propidium monoazide (PMA) combined with direct qPCR is feasible (Supplementary Table 1) $)^{16,28,29}$.

\section{Conclusion}

For routine use, we propose that the elucidation of the mechanism underlying this methodology (which is similar to that of in situ PCR) will lead to the development of a further improved direct qPCR master mix for prokaryotic cells that does not require manual DNA isolation or an automated machine for DNA purification. Because the detection of cells of interest using direct qPCR reaches a level of nearly 1 cell per ml of the test samples, this technology could supply numerous novel findings for genome research and food/environmental/clinical testing for prokaryotic cells. This mechanism could also significantly impact manufacturers that have previously developed a direct qPCR master mix.

\section{Methods}

Strains and culture methods. C. muytjensii ATCC51329 and C. sakazakii ATCC29544 were cultured at $37^{\circ} \mathrm{C}$ for $16 \mathrm{~h}$ using Brain Heart Infusion Broth (Eiken Chemical Co., Ltd., Tokyo, Japan). An aliquot of $5 \mathrm{ml}$ of the culture was placed in a 15-ml Falcon tube (Becton Dickinson Labware, Franklin Lakes, NJ, USA) and subjected to refrigerated centrifugation at $3,000 \times \mathrm{g}$ for $10 \mathrm{~min}$ at $4{ }^{\circ} \mathrm{C}$. The supernatant was removed, and $5 \mathrm{ml}$ of physiological saline was subsequently added to the pellet to prepare a stock live cell suspension of Cronobacter. The live cell suspension was appropriately diluted with physiological saline as in the test sample. Independently, $1 \mathrm{ml}$ of the aforementioned stock of live cell suspension was placed in a $1.5-\mathrm{ml}$ volume microtube (Eppendorf, Hamburg, Germany), and the tube was subsequently immersed in a boiling water bath for $50 \mathrm{sec}$ and immediately quenched. To generate a stock of heat-killed (dead) cell suspension, we confirmed that the bacteria did not thereafter form any colonies on a standard plate count agar medium (SPC agar: Eiken). The viable cell count of C. muytjensii or C. sakazakii live cell suspension was conducted on SPC agar medium, and measurements of turbidity were simultaneously performed at a wavelength of $600 \mathrm{~nm}$ using a spectrophotometer U-2800 A (Hitachi, Tokyo, Japan) to determine the relationship between the live cell count and turbidity.

Direct qPCR measurement of pellets and supernatant obtained through centrifugation of C. muytjensii cell suspension after PCR thermal cycling. The direct qPCR components comprised $0.5 \mu \mathrm{l}$ of $500 \mu \mathrm{g} / \mathrm{ml}$ lysozyme, $6.25 \mu \mathrm{l} 4 \%$ Brij56, $2.5 \mu \mathrm{l}$ 2\% BSA, $0.1 \mu \mathrm{l} 250 \mathrm{mM}$ TSC, $0.1 \mu \mathrm{l} 750 \mathrm{mM} \mathrm{MgCl}, 0.1 \mu \mathrm{l}$ $320 \times$ SYBR Green I, and $15.45 \mu \mathrm{l}$ of SW (total $25 \mu \mathrm{l}$ ). Each C. muytjensii suspension (physiological saline or direct 
qPCR components) was divided into $25-\mu \mathrm{l}$ aliquots and placed into $200-\mu \mathrm{l}$ PCR tubes. The $25-\mu \mathrm{l}$ portions were subjected to PCR thermal cycling involving 50 cycles at $95^{\circ} \mathrm{C}$ for $15 \mathrm{sec}, 60^{\circ} \mathrm{C}$ for $20 \mathrm{sec}$, and $72^{\circ} \mathrm{C}$ for $30 \mathrm{sec}$ and were subsequently recombined into one tube (total $0.25 \mathrm{ml}$ ). A total of $0.25 \mathrm{ml}$ of heat-treated C. muytjensii suspension was centrifuged at $10,000 \times g$ for $5 \mathrm{~min}$ at $4{ }^{\circ} \mathrm{C}$, and the supernatant was transferred to a new microtube.

Freshly prepared saline or direct qPCR components $(0.25 \mathrm{ml})$ were added to the obtained pellets, and an aliquot of $2.5 \mu \mathrm{l}$ of the re-suspension $(0.25 \mathrm{ml})$ was added to $12.25 \mu \mathrm{l}$ of fresh direct qPCR components (the volume of SW was changed from the aforementioned 15.45 to $2.7 \mu \mathrm{l}$; hereafter unless otherwise mentioned, the volume of SW was $15.45 \mu \mathrm{l}$ ), followed by the addition of $12.75 \mu \mathrm{l}$ of the typical PCR master mix described below (that is, $25 \mu$ l of the direct qPCR master mix), corresponding to "Pellet (suspension)" in Table 1. The specific primers for C. muytjensii, ompA_F (the forward primer for ompA gene elongation; 5'-GGATTTAACCGTGAACTTTTCC-3') and $o m p A \_R$ (the reverse primer for $o m p A$ gene elongation; 5' -CGCCAGCGATGTTAGAAGA-3') were used, resulting in the amplification of a $469 \mathrm{bp}$ product $^{30}$. The typical PCR master mix comprised $2 \mu \mathrm{l}$ of $10 \mathrm{pmol} / \mu \mathrm{l}$ ompA_F, $2 \mu \mathrm{l}$ of $10 \mathrm{pmol} / \mu \mathrm{l}$ ompA_R, $0.25 \mu \mathrm{l}$ of 5U/ $\mu \mathrm{l} \mathrm{Ex}$-Taq (Takara-Bio, Ohtsu, Japan), $2.5 \mu \mathrm{l}$ of $10 \times \mathrm{Ex}$-Taq Buffer (Takara-Bio), $2 \mu \mathrm{l}$ of $2 \mathrm{mM}$ dNTP mixture, and $4 \mu \mathrm{l}$ of $10 \times$ SYBR Green I Nucleic Acid Gel Stain $(10,000 \times$ concentrate in DMSO, Lonza Rockland, Inc., Rockland, ME, USA).

Approximately $12.25 \mu \mathrm{l}$ of the direct qPCR components ( $2.7 \mu \mathrm{l}$ of SW ver.) and $12.75 \mu \mathrm{l}$ of the typical PCR master mix (that is, direct qPCR master mix) were also added to an aliquot of $2.5 \mu \mathrm{l}$ of the supernatant following the centrifugation of the aforementioned C. muytjensii suspension, corresponding to "Supernatant" in Table 1 . The thermal cycle program included $1 \mathrm{cycle}$ at $4^{\circ} \mathrm{C}$ for $3 \mathrm{~min}, 50$ cycles at $95^{\circ} \mathrm{C}$ for $15 \mathrm{sec}, 60^{\circ} \mathrm{C}$ for $20 \mathrm{sec}$, and $72^{\circ} \mathrm{C}$ for $30 \mathrm{sec}$, followed by $1 \mathrm{cycle}$ at $95^{\circ} \mathrm{C}$ for $3 \mathrm{~min}$ and a successive melt analysis of the PCR amplicons. Additionally, the $\mathrm{Ct}$ value in $\mathrm{qPCR}$ represents the first PCR cycle at which the fluorescence value resulting from PCR elongation is above the threshold, and subsequently, the Ct value decreases with increasing DNA template concentration in the PCR tube.

Influence of direct qPCR components before and after thermal cycling on the PCR elongation in terms of PCR inhibitors. Ten $25-\mu \mathrm{l}$ portions of the direct $\mathrm{qPCR}$ components were subjected to 50 cycles of PCR thermal cycling and combined with one portion $(0.25 \mathrm{ml})$ to prepare the direct qPCR components (matrices) heated through thermal cycling. Concerning the pellet or supernatant obtained through centrifugation at $10,000 \times g$ for $5 \mathrm{~min}$ at $4^{\circ} \mathrm{C}$ to its one portion, the former was re-suspended in $0.25 \mathrm{ml}$ of freshly prepared direct qPCR components, and then the latter was used as it is for sample matrices (corresponding to Pellet or Supernatant of Heat following PCR thermal cycling in Table 2). Likewise, the same experimental procedure was performed to prepare sample matrices regarding ten $25-\mu$ l portions of the direct qPCR components without PCR thermal cycling (corresponding to Pellet or Supernatant of No heat in Table 2).

Subsequently, the C. muytjensii cells were cultured overnight, washed, and suspended in physiological saline or the direct qPCR components (corresponding to 2 kinds of Pellet or Supernatant matrices in Table 2) with or without PCR thermal cycling, at a concentration of $2.5 \times 10^{6}$ to $10^{9} \mathrm{cfu} / \mathrm{ml}$. To an aliquot of $2.5 \mu \mathrm{l}$ of each bacterial suspension, $12.25 \mu \mathrm{l}$ of direct qPCR components ( $2.7 \mu \mathrm{l}$ of SW ver.) and $12.75 \mu \mathrm{l}$ of the typical PCR master mix (including C. muytjensii ompA forward and reverse primers) were added to perform the PCR.

Examination of C. muytjensii cell morphology in physiological saline or direct qPCR components after the PCR thermal cycling. C. muytjensii cells were cultured overnight and washed, and the bacterial pellet was suspended in physiological saline or direct qPCR components $(0.25 \mathrm{ml})$ at a concentration of $10^{9} \mathrm{cfu} / \mathrm{ml}$. Each suspension was divided into $25 \mu \mathrm{l}$ aliquots and placed into a $200-\mu \mathrm{l}$ PCR tube followed by PCR thermal cycling $\left(50 \mathrm{cycles}\right.$ at $95^{\circ} \mathrm{C}$ for $15 \mathrm{sec}, 60^{\circ} \mathrm{C}$ for $20 \mathrm{sec}$, and $72^{\circ} \mathrm{C}$ for $30 \mathrm{sec}$ ). The contents were combined (total $0.25 \mathrm{ml}$ ). Each combined $0.25-\mathrm{ml}$ bacterial suspension was halved; one half was retained in the original state, and the other half was subjected to centrifugation at $10,000 \times g$ for $5 \mathrm{~min}$ at $4{ }^{\circ} \mathrm{C}$, and the supernatant was recovered. To $0.125 \mathrm{ml}$ of each of the aforementioned bacterial suspensions and supernatants, SYTO9 (Molecular Probes) was added at a ratio of $1.5 \mu \mathrm{l} / \mathrm{ml}$ and incubated at $4{ }^{\circ} \mathrm{C}$ for $15 \mathrm{~min}$ under a safelight. Subsequently, an aliquot of $2.5 \mu \mathrm{l}$ was placed onto a glass slide, covered with a cover slip, and examined on an AxiosKop 2 motplus fluorescence/stereoscopic microscope (LEJ Leistungselektronik Jena GmbH, Jena, Deutschland) to determine whether the bacterial cell emitted $\lambda_{\max } 530 \mathrm{~nm}$ green fluorescence with an argon laser and a $488 \mathrm{~nm}$ excitation.

Similarly, the C. muytjensii suspension $\left(10^{9} \mathrm{cfu} / \mathrm{ml}\right.$; finally $\left.0.25 \mathrm{ml}\right)$ in $25-\mu \mathrm{l}$ aliquots with physiological saline or direct qPCR components, was subjected to PCR thermal cycling, including 50 cycles or no PCR cycles, and the divided portions were pooled, generating a total of $0.25 \mathrm{ml}$. Each suspension $(0.25 \mathrm{ml})$ was centrifuged at $10,000 \times g$ for $5 \mathrm{~min}$ at $4{ }^{\circ} \mathrm{C}$ followed by the removal of the supernatant; the resulting bacterial pellet was suspended with $0.25 \mathrm{ml}$ of physiological saline. Similarly, SYTO9 staining was performed for the measurement of FCM; the FACSCalibur flow cytometer (Becton Dickinson, San Jose, CA, USA) and an argon laser of $488 \mathrm{~nm}$ were used to determine the bacterial cell plots through FSC (forward scattering light) and SSC (side scattering light). When the SYTO9 staining agent intercalated into the intracellular chromosomal DNA, the FL1 filter (of which $\lambda_{\max }$ is $530 \mathrm{~nm}$ by excitation with argon laser irradiation) detected the green fluorescence of the SYTO9, and the FL1 signal was plotted. Although no nuclear staining agents based on propidium iodide (PI) were used, the red fluorescence was collected using the FL3 filter as a reference. The detailed measurement conditions of FCM are presented below:

p1 of Parameter: FSC of Detection, E02 of Voltage, log of Mode; p2 of Parameter: SSC of Detection, 458 of Voltage, log of Mode; 33 of Parameter: FL1 of Detection, 820 of Voltage, log of Mode; p4 of Parameter: FL2 of Detection, 643 of Voltage, log of Mode; p5 of Parameter: FL3 of Detection, 643 of Voltage, log of Mode; p6 of Parameter: FL1-A of Detection, 1.00 of Amp-Gain, lin of Mode; p7 of Parameter: FL1-H of Detection, 1.00 of Amp-Gain; lin of Mode. Compensation was below: FL1 - 47.2 FL2; FL2 - 37.7 FL 1; FL2 - 44.7 FL3; FL 3-36.5 
FL2. Threshold: Primary parameter of FSC-H 0. Total events in FSC-SSC plots: $5 \times 10^{4}$. Hereafter, all the FCM measurements followed the conditions described in this section.

Direct qPCR measurements of the $C$. muytjensii cells subjected to fixation and FCM to determine morphology retention after PCR thermal cycling. Two $500-\mu l$ portions of the C. muytjensii cells $\left(9.3 \times 10^{8} \mathrm{cfu} / \mathrm{ml}\right)$ were cultured overnight and centrifuged at $3,000 \times g$ for $10 \mathrm{~min}$ at $4{ }^{\circ} \mathrm{C}$. The supernatant was removed, and $500 \mu \mathrm{l}$ of fixation A (4\% paraformaldehyde, PFA) or fixation B (methanol/acetic acid $=3 / 1$ ) was subsequently added to the pellet. The mixture was incubated overnight at $4{ }^{\circ} \mathrm{C}$ to cross-link the chromosomal DNA in the C. muytjensii cells and cell wall proteins to fix the DNA in the bacterial cells. Next, the cells were washed 3 times with $500 \mu \mathrm{l}$ of physiological saline and were subsequently suspended in $250 \mu \mathrm{l}$ of physiological saline. The recovery rate of bacterial cells to pellet after each centrifugation for washing was experimentally determined to be $80 \%$ (legend of Table 5), and centrifugation was conducted four times. Thus, the concentration of the C. muytjensii suspension was estimated to be $7.6 \times 10^{8} \mathrm{cfu} / \mathrm{ml}$. To an aliquot of $2.5 \mu \mathrm{l}$ of this suspension, $12.25 \mu \mathrm{l}$ of the direct qPCR components $(2.7 \mu \mathrm{l}$ of SW ver.) and $12.75 \mu \mathrm{l}$ of the typical PCR master mix (C. muytjensii ompA specific primers) were added, and the direct qPCR was subsequently performed for 30 cycles.

Next, twenty $27.5-\mu \mathrm{l}$ aliquots of the PCR products were combined into one portion and subjected to centrifugation at 3,000 $\times \mathrm{g}$ for $10 \mathrm{~min}$ at $4{ }^{\circ} \mathrm{C}$. A $5-\mu \mathrm{l}$ aliquot of this supernatant was electrophoresed on a $2 \%$ agarose gel, followed by $1 \times \mathrm{SYBR}^{\circledR}$ Gold nucleic acid gel staining $(10,000 \times$ concentrate in DMSO, Lonza Rockland, Inc., Rockland, ME, USA; hereafter, all gel staining was performed with SYBR Gold stain). After the residual supernatant was removed, $200 \mu \mathrm{l}$ of physiological saline was subsequently added (estimated C. muytjensii cell number was $1.5 \times 10^{8}$ cells $/ \mathrm{ml}$, considering the recovery loss due to a single centrifugation). The SYTO9 (Invitrogen) was added at a concentration of $1.5 \mu \mathrm{l} / \mathrm{ml}$, followed by FCM measurements.

Method to reveal that the reaction mechanism of the direct qPCR is similar to that of in situ PCR. Following the aforementioned fixation procedure, $500 \mu \mathrm{l}$ of $C$. muytjensii cells $\left(4.3 \times 10^{8} \mathrm{cfu} / \mathrm{ml}\right)$ were cultured overnight and subjected to centrifugation, followed by removal of the supernatant, and $500 \mu \mathrm{l}$ of fixation $\mathrm{B}($ methanol/acetic acid $=3 / 1)$ was added to the pellet, followed by incubation overnight at $4^{\circ} \mathrm{C}$. As a control, a sample in which the fixation was not performed was obtained using the same volume of physiological saline instead of fixation agent. Next, the cells were washed 3 times with $500 \mu \mathrm{l}$ of saline and suspended in $250 \mu \mathrm{l}$ of saline. Because the recovery rate of bacterial cells to pellet after each centrifugation for washing was $80 \%$ (legend of Table 5) and centrifugation was conducted four times, the concentration of the C. muytjensii cells was estimated to be $3.5 \times 10^{8}$ cells $/ \mathrm{ml}$.

To an aliquot of $2.5 \mu \mathrm{l}$ of this suspension, $12.25 \mu \mathrm{l}$ of the direct $\mathrm{qPCR}$ components $(2.7 \mu \mathrm{l} \mathrm{SW}$ ver.) and $12.75 \mu \mathrm{l}$ of the typical PCR master mix (total coliform-specific primers of $16 \mathrm{~S} \_2751 \mathrm{~F}$ and 23 S_5201 R instead of C. muytjensii ompA primers) mentioned below were added to perform direct qPCR for retaining a fraction of the long PCR amplicons in C. muytjensii cells ${ }^{20}$. The forward primer $16 \mathrm{~S} \_2751 \mathrm{~F}\left(5^{\prime}\right.$-CTACAATGGCGCATACAAAGAGAAGCGACCT-3') and reverse primer 23 S_5201 R (5'-CTTCTCCCGAAGTTACGGCACCA- $\left.3^{\prime}\right)$ were used, and the principal elongated amplicon length was set at $2,451 \mathrm{bp}^{20}$. The thermal cycle profile included 1 cycle at $4{ }^{\circ} \mathrm{C}$ for $3 \mathrm{~min} ; 50$ cycles at $95^{\circ} \mathrm{C}$ for $15 \mathrm{sec}, 60^{\circ} \mathrm{C}$ for $20 \mathrm{sec}$, and $72^{\circ} \mathrm{C}$ for $3 \mathrm{~min}$, followed by $1 \mathrm{cycle}$ at $95^{\circ} \mathrm{C}$ for $3 \mathrm{~min}$. Before or after the direct qPCR elongation, the 20 portions of the pre- or post-PCR products for C. muytjensii cells treated with a preliminary fixation B or no fixation were combined and subjected to centrifugation. The pellet was washed three times with $500 \mu \mathrm{l}$ of saline to completely remove the long DNA amplicons potentially adsorbed onto the cell walls of C. muytjensii, and DNA purification was performed using the QuickGene SP kit DNA tissue to determine the presence of long DNA amplicons in the cells (Fuji Photo Film Co., Ltd., Tokyo, Japan).

Comparing the direct $q P C R$ with $q P C R$ following crude DNA extraction or DNA purification methods to determine the detection limits for Cronobacter cells. From the C. sakazakii ATCC29544 and C. muytjensii ATCC51329 cultured overnight, for Cronobacter DNA standards, purified DNA free from RNA contamination was obtained following the typical SDS/protease treatment and phenol/chloroform extraction, followed by precipitation with ethanol together with RNase treatment to confirm the ratio of the optical density $\mathrm{OD}_{260 \mathrm{~nm}} / \mathrm{OD}_{280 \mathrm{~nm}}$ in a range of 1.8 to $2.0^{16,31}$. In contrast, after the aforementioned overnight cultures were washed with physiological saline, and the cells were serially diluted with SW. A 1-ml Cronobacter cell suspension was centrifuged, and the supernatant was removed. To each bacterial pellet, $12.25 \mu \mathrm{l}$ of the direct $\mathrm{QPCR}$ components $(2.7 \mu \mathrm{l} \mathrm{SW}$ ver.) and $12.75 \mu \mathrm{l}$ of the typical PCR master mix (ompA), i.e., the direct qPCR master mix, were added for direct qPCR.

To examine the detection limits for Cronobacter cells by qPCR with purified DNA, DNA purification using the FastPure DNA Kit (Takara Bio) was performed for $1 \mathrm{ml}$ bacterial suspension, and subsequently, an aliquot of $2.5 \mu \mathrm{l}$ of purified DNA solution $(200 \mu \mathrm{l})$ was included for $\mathrm{qPCR}$ according to the manufacturer's instructions. Crude extraction through boiling $1 \mathrm{ml}$ bacterial suspension for $10 \mathrm{~min}$ was performed, and subsequently, an aliquot of $2.5 \mu \mathrm{l}$ of the supernatant obtained after centrifugation of the boiled suspension $(1 \mathrm{ml})$ was included for qPCR.

As a control (qPCR standards using diluted purified DNA), $2.5 \mu \mathrm{l}$ of the isolated DNA solutions was added to a new PCR tube at $6.5 \mathrm{fg}$ to $650 \mathrm{pg} / \mathrm{PCR}$ tube, followed by the addition of the direct qPCR master mix. Because 1 cell of the bacteria was estimated to contain 5 fg of chromosomal DNA, each amount of DNA included in the PCR was identical to that of the associated bacterial cell number obtained from the centrifugation of each $1 \mathrm{ml}$ bacterial suspension. 


\section{References}

1. Maji, A. et al. Expression profiling of lymphnodes in tuberculosis patients reveal inflammatory milieu at site of infection. Sci. Rep.5, $15214(2015)$

2. Pinhata, J. M. et al. Rapid detection of Mycobacterium tuberculosis complex by real-time PCR in sputum samples and its use in the routine diagnosis in a reference laboratory. J. Med. Microbiol. 64, 1040-1045 (2015).

3. Wood, R. C. et al. Detection of Mycobacterium tuberculosis DNA on the oral mucosa of tuberculosis patients. Sci. Rep. 5, 8668 (2015).

4. O'Mahony, J. \& Hill, C. Rapid real-time PCR for detection and quantitation of Mycobacterium avium subsp. paratuberculosis DNA in artificially contaminated milk. Appl. Environ. Microbiol. 70, 4561-4568 (2004).

5. Tasara, T. \& Stephan, R. Development of an F57 sequence-based real-time PCR assay for detection of Mycobaterium avium subsp. paratuberculosis in milk. Appl. Environ. Microbiol. 71, 5957-5968 (2005).

6. Whan, L., Ball, H. J., Grant, I. R. \& Rowe, M. T. Development of an IMS-PCR assay for the detection of Mycobacterium avium subsp. paratuberculosis in water. Lett. Appl. Microbiol. 40, 269-273 (2005).

7. Manoj, K. M. N. \& Venkitanarayanan, K. S. Cloning and sequencing of the ompA gene of Enterobacter sakazakii and development of an ompA-targeted PCR for rapid detection of Enterobacter sakazakii in infant formula. Appl. Environ. Microbiol. 72, 2539-2546 (2006).

8. Abu Al-Soud, W. \& Rådström, P. Effects of amplification facilitators on diagnostic PCR in the presence of blood, feces, and meat. J. Clin. Microbiol. 38, 4463-4470 (2000).

9. Vollmer, T., Knabbe, C. \& Dreier, J. Comparison of real-time PCR and antigen assays for detection of Hepatitis E virus in blood donors. J. Clin. Microbiol. 52, 2150-2156 (2014).

10. Anderson, R. J., Groundwater, P. W., Todd, A. \& Worsley, A. J. Antibacterial agents chemistry, mode of action, mechanism of resistance and clinical applications: Section 1 Introduction to Microorganisms and Antibacterial chemotherapy. Available at: http:// www.beck-shop.de/fachbuch/vorwort/9780470972458 Intro_001.pdf (Accessed: $9^{\text {th }}$ December 2015) (2012).

11. Shirasu, N. \& Kuroki, M. Simultaneous genotyping of single-nucleotide polymorphisms in alcoholism-related genes using duplex and triplex allele-specific PCR with two-step thermal cycles. Anal. Sci. 30, 1093-1096 (2014).

12. Okamoto, H. et al. Direct amplification of Escherichia coli $\mathrm{O} 157$ vero toxin genes from human faeces by the polymerase chain reaction. Ann. Clin. Biochem. 36, 642-648 (1999).

13. AlShahni, M. M. et al. Direct colony PCR of several medically important fungi using ampdirect ${ }^{\circledR}$ plus. Jpn. J. Infect. Dis. 62, 164-167 (2009).

14. Kerdsin, A. et al. Development of triplex SYBR green real-time PCR for detecting Mycoplasma pneumonia, Chlamydophila pneumonia, and Legionella spp. without extraction of DNA. Jpn. J. Infect. Dis. 63, 173-180 (2010).

15. Zhang, Z., Kermekchiev, M. B. \& Barnes, W. M. Direct DNA amplification from crude clinical samples using a PCR enhancer cocktail and novel mutants of Taq. J. Mol. Diagn. 12, 152-161 (2010).

16. Soejima, T. et al. Method to detect only live bacteria during PCR amplification. J. Clin. Microbiol. 46, 2305-2313 (2008).

17. Minami, J., Yoshida, K., Soejima, T., Yaeshima, T. \& Iwatsuki, K. New approach to use ethidium bromide monoazide as an analytical tool. J. Appl. Microbiol. 109, 900-909 (2010).

18. Soejima, T., Schlitt-Dittrich, F. \& Yoshida, S.-I. Rapid detection of viable bacteria by nested polymerase chain reaction after ethidium monoazide treatment. Anal. Biochem. 418, 286-294 (2011).

19. Minami, J.-I., Soejima, T., Yaeshima, T. \& Iwatsuki, K. Direct real-time PCR with ethidium monoazide: A method for the rapid detection of Cronobacter sakazakii in powdered infant formula. J. Food Prot. 75, 1572-1579 (2012).

20. Soejima, T., Minami, J.-I., Yaeshima, T. \& Iwatsuki, K. An advanced PCR method for the specific detection of viable total coliform bacteria in pasteurized milk. Appl. Microbiol. Biotechnol. 5, 485-497 (2012a).

21. Soejima, T., Minami, J.-I. \& Iwatsuki. K. Rapid propidium monoazide PCR assay for the exclusive detection of viable Enterobacteriaceae cells in pasteurized milk. J. Dairy Sci. 95, 3634-3642 (2012b).

22. Wilson, I. G. Inhibition and facilitation of nucleic acid amplification. Appl. Environ. Microbiol. 63, 3741-3751 (1997).

23. Zhu, J. et al. Multiplex allele-specific amplification from whole blood for detecting multiple polymorphisms simultaneously. Genet. Test Mol. Biomarkers. 17, 10-15 (2012).

24. Khan, S. P., Ghani, R. \& Yaqub, Z. Single step PCR for the identification of low density lipoprotein Receptor (LDL-R) gene mutations. Pak. J. Med. Sci. 30, 830-833 (2014).

25. Beveridge, T. J. Structures of gram-negative cell walls and their derived membrane vesicles. J. Bacteriol. 181, 4725-4733 (1999).

26. Shi, R. \& Chiang, V. L. Facile means for quantifying microRNA expression by real-time PCR. Biotechniques 39, 519-525 (2005)

27. Nuovo, G. J. In situ PCR: protocols and applications. Genome Res. 4, S151-S167 (1995).

28. Rudi, K., Moen, B., Dromtorp, S. M. \& Holck, A. L. Use of ethidium monoazide and PCR in combination for quantification of viable and dead cells in complex samples. Appl. Environ. Microbiol. 71, 1018-1024 (2005).

29. Nocker, A. \& Camper, A. K. Selective removal of DNA from dead cells of mixed bacterial communities by use of ethidium monoazide. Appl. Environ. Microbiol. 72, 1997-2004 (2006).

30. Mohan Nair, M. K. \& Venkitanarayanan, K. S. Cloning and sequencing of the ompA gene of Enterobacter sakazakii and development of an ompA-targeted PCR for rapid detection of Enterobacter sakazakii in infant formula. Appl. Environ. Microbiol. 72, 2539-2546 (2006).

31. Soejima, T. et al. Photoactivated ethidium monoazide directly cleaves bacterial DNA and is applied to PCR for discrimination of live and dead bacteria. Microbiol. Immunol. 51, 763-775 (2007).

\section{Author Contributions}

T.S. designed the experiments, performed the analysis, and wrote the paper. J.-Z.X. edited the paper. F.A. supervised the study. All authors have given approval to the final version of the manuscript.

\section{Additional Information \\ Supplementary information accompanies this paper at http://www.nature.com/srep}

Competing financial interests: The authors declare no competing financial interests.

How to cite this article: Soejima, T. et al. A novel mechanism for direct real-time polymerase chain reaction that does not require DNA isolation from prokaryotic cells. Sci. Rep. 6, 28000; doi: 10.1038/srep28000 (2016).

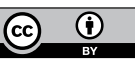

This work is licensed under a Creative Commons Attribution 4.0 International License. The images or other third party material in this article are included in the article's Creative Commons license, unless indicated otherwise in the credit line; if the material is not included under the Creative Commons license, users will need to obtain permission from the license holder to reproduce the material. To view a copy of this license, visit http://creativecommons.org/licenses/by/4.0/ 